\title{
Criminal Investigation of the Corruption Crimes: Evidence and Procedure in an Interdisciplinary Approach
}

\section{La investigación criminal en delitos de corrupción: La prueba y el procedimiento desde una aproximación interdisciplinaria}

\author{
Delia Magherescu ${ }^{1}$ \\ Gorj Bar Association - Romênia \\ delia_magherescu@yahoo.com \\ http://orcid.org/0000-0003-0939-1549
}

\begin{abstract}
AвSTRACT: Approaching criminality in an interdisciplinary context has concerned practitioners in the last decades. The same situation is observed in criminal cases having as object the criminal investigation of corruption crimes, knowing the fact that this phenomenon is still into the judicial authorities' attention. In practice, there is a substantial jurisprudence on this topic. The current paper focuses on criminal investigation of the corruption in an interdisciplinary context, including elements of forensic investigation, gathering evidence by means of forensic science, as well as their administration during the criminal proceedings. Moreover, researching the current topic aims at analyzing phenomenon from the perspective of the judicial bodies' efforts of assuring functions of discovering and preventing corruption crimes, as well as punishing defendants during the criminal proceedings. In order to achieve this goal, the paper is designed in a qualitative research, with comparative elements and aspects of jurisprudence in criminal matters. KeYwords: Criminal investigation; Criminal proceedings; Corruption crimes; Forensic evidence.
\end{abstract}

RESUMEN: La aproximación a la criminalidad desde un contexto interdisciplinario ha preocupado a los operadores del sistema penal a lo largo de las últimas

1 Doctor in Law since 2005 awarded at the State University of Moldova, Republic of Moldova. 
décadas. Esa preocupación alcanza también a la investigación criminal de los delitos de corrupción, un fenómeno que ya es objeto de atención por parte de las autoridades judiciales. De hecho, hay una importante jurisprudencia sobre la materia. El presente artículo se centra en la investigación criminal de la corrupción en un contexto interdisciplinario, abordando cuestiones relativas a la investigación forense, la consecución de pruebas por medio de las ciencias forenses, y la gestión de ese material probatorio en el marco del procedimiento penal. Junto a ello, el fenómeno se analiza desde una perspectiva interdisciplinaria, que tiene en cuenta el trabajo de los órganos jurisdiccionales en materia de prevención de nuevos delitos de corrupción y de reeducación de los acusados. A estos efectos, el artículo está diseñado como una investigación cualitativa, con elementos comparativos y análisis de la jurisprudencia en materia penal.

Palabras-clave: Investigación criminal; Procedimiento penal; Delitos de corrupción; Pruebas forenses.

Summary: 1. General Background. - 2. Criminal investigation of corruption crimes by means of forensic science. - 3. Approaching crimes of corruption in the judiciary. - 4. Reflection of criminal sciences over the corruption phenomenon. -5 . Legal instruments on fighting corruption crimes. - 6. Conclusions. Bibliography.

\section{General background}

Antisocial phenomena are currently so spread in the contemporary society. The de facto situation states that the corruption crimes are not excepted from this situation, they being also occurred within several fields of activity, from politics to public administration, from justice to private area. Moreover, the economic areas are "infected" with the corruption phenomenon, which restrains basically the development of economy of every state, as well as the entire society.

The democratic values, based on the principles of rule of law $^{2}$ and other constitutional ones, as well as the legislation into force, are,

2 POPOVA, Maria; POST, Vincent. Prosecuting high-level corruption in Eastern Europe, Communist and Post-Communist Studies. v. 51, p. 231-244, 2018. 
within this framework, incompatible with the development of corruption phenomenon, whose consequences are very harmful for society.

In order to combat the corruption phenomenon, the countries through their judicial authorities have in focus the following issues:

(i) adopting a legal framework well grounded to face pressures arisen from committing corruption crimes;

(ii) strengthening the capacity of fighting corruption crimes, as well as those assimilated with the corruption, in such a manner to lead to diminishing cases of corruption;

(iii) setting up a professional body of specialists in all areas of activity, especially within the public area;

(iv) achieving efficient justice under the principles of respecting law and public dignities;

(v) implementing efficient judicial mechanisms in criminal matters to conclude to achieving criminal procedural functions.

The fulfillment of the above stated requirements are possible with the implementation of legal instruments provided by the state's authorities within an interdisciplinary framework. In order to achieve these goals, the states participate with diversified programs and mechanisms that seek to diminish and combat corruption crimes as much as possible.

First of all, the activity in the field of judiciary is a remarkable one, as long as it is carried out outside of the influence area of corruption crimes. The judicial system in criminal matters provides a real guarantee in applying the basic principles of criminal proceedings, and solving criminal cases, especially of corruption ones, under the condition of legality and justified criteria, also based on conclusive, pertinent and genuine evidence, which conduct to finding truth in criminal cases of corruption.

Secondly, the forensic science has contributed significantly to solving cases of corruption. In practice, it is well known that the forensic investigation of corruption crimes has useful consequences for the judicial bodies in their activity of criminal investigation. It particularly refers to the instruments of gathering evidence, the modality of discovering, preserving, collecting and examining them, as well as the means of administering forensic evidence, during the criminal proceedings. Last but not least, it is about the procedure of achieving criminal investigation in special cases, as it will be emphasized in the next chapters. 
Thirdly, as a rule, researching corruption phenomenon is the object of criminal sciences, whose intrinsic approach is indispensable. It is considered so, due to the fact that it is very important for the law enforcement agencies to analyze the corruption phenomenon from all perspectives, both substantively and procedural, for a better understanding of de facto judicial situation in the field of practice. Despite this feature, the criminal investigation of corruption crimes is the key factor of solving criminal cases, based on genuine evidence. It includes, among the other means of evidence, the forensic evidence, due to the fact that in several cases, digital devices are used by the law enforcement agencies in order to gather evidence in these cases $^{3}$.

Thus, the criminal activity of committing corruption crimes could be discussed in accordance with the study of criminal phenomena, committed at macro-level, whose consequences have repercussions on the entire society.

Implementing certain solutions, which must be taken into account in the future in purpose to reduce corruption crimes, is the key factor among public authorities of every country. These aspects are the competence of criminologists, who are usually involved in promoting certain frame-instruments adopted at domestic level to streamline the fight against corruption crimes.

For these reasons, approaching corruption crimes in an interdisciplinary area is necessary. This approach characterizes the current paper in both theoretical and practical fields, which comes to support the law enforcement through practical solutions they could take into account for the future, in order to prevent and combat any kind of corruption crimes.

The content of the current paper as well as its structure has facilitated the qualitative research of the topic, by approaching corruption crimes in an interdisciplinary way. Thus, dialectical connection between the forensic science on the one hand and elements of the courts of law jurisprudence in criminal matters on the other hand, is more than necessary. Actually, it is essential in purpose to outline certain pertinent

3 HIGH COURT OF CASSATION AND JUSTICE OF ROMANIA. Decision no. 385/A/2019. Available at: https://www.scj.ro. Accessed on May 21, 2020. 
proposals of modifying legal framework into force in the matter of combating corruption crimes, as well as implementing efficient programs in fighting this scourge.

Finally, the jurisprudence in criminal matters states an ample vision upon the aspects regarding the size of corruption phenomenon, as well as regarding the means of criminal investigation. The drawbacks the judicial bodies are faced with, were taken into account in carrying out the current paper, including those regarding the functions of investigation of corruption crimes, forensic investigation, as well as of discovering evidence.

It is considered so, due to the fact that the same importance features both the activity of discovering corruption crimes and the forensic investigation of them. Gathering evidence makes from this activity a complex one, based on strong principles, such as efficiency, rapidity, impartiality, firmness, legality, all being completed by the European principles in criminal matters, such as presumption of innocence and due process, advanced by the European Convention on Human Rights and promoted by the European Court of Human Rights' jurisprudence ${ }^{5}$.

\section{Criminal investigation of Corruption CRimes by means of FORENSIC SCIENCE}

According to the general principles of forensic science, committing offenses produces modification in the environment ${ }^{6}$. From this point of

4 CRIMINAL DECISION no. 294/A of 24 March 2020 of the Court of Appeal of Bucharest; CRIMINAL DECISION no. 66 of 3 March 2020 of the High Court of Cassation and Justice of Romania; CRIMINAL DECISION no. 201 of 14 February 2020 of the Court of Appeal of Bacau. Available at: http:// www.pna.ro. Accessed on April 26, 2020). See also COMMUNICATION no. 238/VIII/ of 15 April 2020, COMMUNICATION no. 236/VIII/3 of 15 April 2020, COMMUNICATION no. 234/VIII/ of 15 April 2020 of the Anti-Corruption National Department. aAvailable at: http://www.pna.ro. Accessed on April 26, 2020.

5 HUDOC. European Court of Human Rights. Available at: https://hudoc.echr. coe.int. Accessed on April 28, 2020.

6 STANCU, Emilian. Tratat de Criminalistica. Bucharest: Universul Juridic, 2015. 
view, is has been argued that the scientific methods and techniques are means of forensic science, which may assure the successful of investigation of criminal cases ${ }^{7}$.

The forensic science provides a detailed field of action regarding the criminal investigation of offenses. No exception from this rule, the corruption crimes present a particular feature, determined by the criminal modus operandi that the perpetrators choose to adopt in their criminal behaviours.

It is well-known that, during the activity of criminal investigation, the main aim is that of discovering crimes. The activity of discovering corruption crimes is then followed by the other ones consisting in gathering evidence in purpose to proceed to send them to the forensic laboratory in order to carry out a scientific analysis.

Moreover, doctrine has emphasized that the forensic investigation activity does not involve exclusively the laboratory procedure. The crime scene investigation is equally important in this matter ${ }^{8}$. From this point of view, the legal doctrine has appreciated that the forensic science "is a field which includes a series of scientific methods and rules, intended to carry out certain procedural acts or procedural activities, starting even from the moment of investigating crime scene".

As a general rule, a specific feature of the corruption crimes is the character of being subject of flagrant action, organized by the judicial bodies in close cooperation with denouncers. From this perspective, it could be stated that the forensic investigation of the corruption crimes does not present difficulties during the activity of gathering evidence regarding the circumstances of crime and identity of perpetrator.

It is obvious that organizing flagrant action is more valuable within the activity of gathering evidence, as long as the forensic investigation bodies need pertinent, conclusive and useful evidence in order for them to solve the criminal cases. In this regard, the forensic examinations of

7 PALCU, Pavel. Necesitatea diversificarii regulilor tactice criminalistice aplicabile in cercetarea la fata locului. Pro Lege, n. 4, p. 77-81, 2018.

8 TRIF, Valentin; PETRE, Adrian. Cercetarea locului faptei in cazul constatarii infractiunilor de coruptie. Curierul Judiciar, n. 8, p. 453-458, 2017.

9 STANCU, Emilian, op. cit., 2015. 
electronic devices and recording surveillance also electronically come to provide genuine evidence for the judicial bodies ${ }^{10}$.

Thus, from the point of view of the way in which the forensic science acts within the judicial activity of investigation of the corruption crimes, some activities which particularly refer to discovering crimes, gathering evidence, fixing, preserving, picking up, transporting and analyzing them in the laboratory must be mentioned. The above stated activities will be carried out by the forensic expert, appointed to investigate the corruption crimes, in order to gather genuine evidence.

Another forensic mean of gathering evidence in cases of corruption is that of the perpetrator's fingerprint examination. Usually, in cases of corruption, the banknotes are beforehand marked with adequate chemical substance, which can subsequently be examined exclusively in the fluorescent light. Once the perpetrator touches them, then the substance covered penetrates the perpetrator's fingerprints ${ }^{11}$.

The main argument of forensic means is that of the scope aimed during the judicial activity. It is about finding truth in criminal cases of corruption, regarding the acts and the circumstances they were committed in, as well as the perpetrators. Moreover, the forensic investigators are the owner of both logical and psychological syllogisms, they use in the judicial activity related to the forensic investigation of corruption crimes. They suppose minimal efforts, reduced costs and a minimum time period.

The operative activity of gathering forensic evidence is the key factor within the process of achieving forensic investigation of corruption crimes. This principle concludes to fulfilling pertinent evidence, gathered from the crime scene. Otherwise, the deterioration of evidence will result in compromising them, and implicitly in arising doubts regarding the relation established between those evidence and criminal case, whose solution is requested, based on legal and justified judicial decision. Thus, the value of evidence will be uncertain during the process of establishing truth by the judicial bodies.

10 HIGH COURT OF CASSATION AND JUSTICE OF ROMANIA. Decision no. 381/A/2019. Available at: https://www.scj.ro. Accessed on May 21, 2020.

11 This is the most common method used by the forensic experts in the activity of gathering evidence on fingerprints in cases of corruption crimes. 
At the same time, the conclusive evidence is relevant in the activity of forensic investigation of corruption crimes. Infringing the conclusive feature of evidence will then conduct to compromising them as well as to appreciating them as being unessential for the activity of solving criminal cases, as a consequence they will be removed from the criminal proceedings.

Last but not least, the usefulness of evidence is essential to investigate the criminal cases. Infringing this feature will conclude inevitably to their inefficacy. As a consequence, the evidence which are not useful for criminal cases cannot clarify de facto aspects related to the way of committing corruption crimes.

All these issues, even led to judicial technique, have particular relevance during the forensic investigation activity of corruption crimes, due to the fact that gathering pertinent, conclusive and genuine evidence depends on the forensic experts' efficiency in developing activity of forensic investigation of the crime scene.

Basically, the object of realizing forensic investigation of corruption crimes is given by the specific methods and proceedings used, achieved either through the investigations which belong to forensic science or taken over the other sciences ${ }^{12}$.

Moreover, through legal instruments provided by the forensic science to judicial bodies, the manner of realizing activities and duties outlined, as well as the objective rules and criteria of appreciating results and quality of evidence gathered during the forensic investigation activities will be established. It is considered so, due to the fact that, by default of legal evidence to highlight beyond any reasonable doubt that the crime exists and was committed by the defendant, the court of law is not entitled to pronounce the judicial decision on defendant's conviction.

The evidence administered during the criminal proceedings highlight that the defendant has required and received money and other gains from several persons. In this context, it has been enough for the

12 The forensic science works in close connection with other sciences, such as physics, chemistry, legal medicine a.s.o., they join dialectical entire mechanisms of solving criminal cases. The professionals work in an interdisciplinary framework in order to familiarize them with proceedings and techniques specific. 
court of law to state beyond any reasonable doubt that the crime exists and was committed by defendant with guilt. During the appeal procedure, the court of law stated that the environmental conversations, intercepted and recorded between defendant and denouncing witness, are not enough to convince the court of law that the defendant has committed the crime of taking bribery as described in the indictment act ${ }^{13}$.

The court of law must rely pronouncing decision on evidence which conclude beyond any reasonable doubt the existence of criminal act, which must prove the accusation formulated by the prosecutor during the investigation phase. As a consequence, other means of evidence must be submitted by the prosecutor and administered by the court of law during the judgment which establish that the defendant is the person who committed the crime of corruption. For these reasons, the appeal court of law has voided the sentence of the first instance and acquitted the defendant regarding the crime of taking bribery ${ }^{14}$.

Nevertheless, the judicial solution pronounced by the court of appeal is not justified, as long as the evidence of audio-video recording cannot be removed from the criminal case simply because there is no other evidence administered in the criminal case to corroborate each other in purpose to pronounce such decisions.

\section{APPROACHING CRIMES OF CORRUPTION IN THE JUDICIARY}

Approaching corruption crimes within the judicial framework supposes different situations according to the circumstances in which the crimes were committed. It is relevant in such cases that there is no unanimity of features brought together for similar cases and, for this reason, their particularities generate special ways of investigation and judgment as well. In this context, some relevant criminal cases of corruption have been in the practitioners' attention, which will be discussed in the current chapter. Nevertheless, they are not limited to

13 Ibidem.

14 COURT OF LAW OF ORADEA. Criminal Decision no. 446 of 2015. Available at: https://legeaz.net/spete-penal-curtea-de-apel-oradea-2015/luarea-de-mita-art-289-ncp-19-06-2015-jar. Accessed on September 2, 2020. 
these ones, but more particularly they highlight the manner in which the judicial bodies proceed to solve criminal cases of corruption in special circumstances.

For jurisprudence in criminal matters, a special attention is arisen for cases of corruption committed under several circumstances or under special procedure of admitting the guilt agreement. This is because, in practice many times corruption crimes involve either taking bribery, giving bribery, or other kinds of crimes, such as trafficking in influence or buying influence, on the other hand. On the other hand, there are many defendants in the same case, but only some of them choose their case to be investigated and judged under the special procedure of guilt agreement, while other ones, under the ordinary procedure.

Case 1: Corruption crimes committed under several circumstances

Discussing corruption crimes in the judiciary, it has been emphasized that the specific feature of modus operandi used by perpetrator makes that most of the times the denouncers in criminal cases have the judicial status of witnesses-denouncer. They know better the circumstances in which the crime was committed and, for this reason, the evidence by witnesses is obviously in this context. From this point of view, the witnesses-denouncer join the procedural rights during the criminal procedure, which support them, on the other hand, and help the judicial bodies to find the truth in criminal cases, as well as to solve them legally and justified, on the other hand. However, in practice, it is relevant that every witness-denouncer has a particular interest in the criminal case, consisting in applying judicial facilities.

The court of law has stated that the witness-denouncer, also defendant in criminal case, has provided the judicial bodies with evidence of the criminal activity committed by the other defendants, accused in the same case and sent to trial for committing the crimes of trafficking in influence and taking bribery. The court of first instance has stated that the witness-denouncer's information is corroborated with other evidence administered in criminal case. However, the entire means of evidence prove that he did not have a sincere behaviour regarding the real involvement in criminal activity. Moreover, the witness-denouncer tried skilfully to minimize or even to eliminate his contribution in committing 
criminal activity ${ }^{15}$. In fact, the court of law has retained that the defendants were involved in the illegal financial support of the transport ministry' electoral campaign, in the exchange of a public contract signed for a huge amount of money. In the case presented above, there is an evident disproportion between the value of the witness-denouncer's information and the amount of money. Therefore, the witness-denouncer's statements regarding the aspects involved are doubtfully. In fact, the value of bribery is proved only by the denunciation and the witness-denouncer's statement, who was examined sincere at the polygraph test.

Nevertheless, the court of law has stated that the evidence is not enough to prove that the witness-denouncer gave the money as bribery to defendant.

From a practical perspective, the value of bribery is a relevant issue both from the point of view of the material object of corruption crime, which should be determined, but not presumptive or estimated ${ }^{16}$, as well as from the point of view of the special measure of seizure, as proceeds gathered from committing crime of corruption ${ }^{17}$.

De facto situation states that usually defendants deny committing crime of taking bribery. In spite of the oscillating behaviour during the investigation and judgment phases of criminal proceedings, which cannot be considered as an evidence of guilt, only the denunciation as well as the denouncer's testimony (being considered sincere at the polygraph examination $)^{18}$ remain in the means of evidence administered by the judicial bodies. They cannot be appreciated as conclusive and sufficient evidence to prove the defendant's guilt for the accusation of taking bribery, as mentioned in the entire elements, such as the value of material object ${ }^{19}$.

15 HIGH COURT OF CASSATION AND JUSTICE OF ROMANIA. Decision no. 121/A/2019. Available at: https://www.scj.ro. Accessed on May 21, 2020. evidence, it can be distorted by the involved person's behaviour, thus it does not provide absolute certainty evidence regarding the real behaviour either simulated or sincere.

19 HIGH COURT OF CASSATION AND JUSTICE OF ROMANIA. Decision no. 121/A/2019. Available at: https://www.scj.ro. Accessed on May 21, 2020. 
Taking into account the principle applied in cases of crimes committed under several circumstances, the court of law has to apply the appropriate penalty, along with a proportion of penalty for each circumstance retained for the defendant's criminal act committed.

First of all, in order to solve legally and justified the criminal cases of corruption, the courts of law are focused on the activity of applying penalty, if the evidence administered in criminal cases result beyond any reasonable doubt that the crime exists and was committed by defendant under the guilt stated by the indictment act. Administering evidence by the judicial bodies implies a procedure within the standardized conventional limits of the ordinary procedure. It is considered so, due to the fact that, according to provisions in criminal matters, the judicial body is entitled to administer evidence both in accusation and in defense.

In other words, in cases in which there are no conclusive, pertinent and genuine evidence to conclude that the accusation formulated by the prosecutor during the investigation phase is proven, then the defendants are entitled to the right to propose evidence in defense, on the one hand, and the judicial body is obliged to administer them, on the other hand, according to Article 6 para 1 of the European Convention on Human Rights. In this regard, the provision stipulates the fundamental principle of equality of arms during the criminal proceedings, establishing thus a balance between accusation and defense.

De iure, the principle of in dubio pro reo, also into force, states that if a doubt regarding the evidence administered in criminal case exists, it must be interpreted in the defendants' advantage, because the judicial decision cannot be pronounced on doubtful evidence, but only on pertinent, conclusive and genuine evidence.

In order for the criminal punishments to be applied by the courts of law, the procedure of administering evidence in criminal cases of corruption is one very well determined, both from the point of view of proceedings and of applying penalty as well.

Secondly, applying penalty in criminal cases of corruption supposes a particular approach from the perspective of the judicial authorities' involvement in solving criminal cases. Equally, applying penalty must be viewed under the imperative of achieving judicial act in criminal cases of all constitutive elements, consisting in discovering 
perpetrators and establishing their guilt based on conclusive, pertinent and genuine evidence, according to Article 6 par. 2 of the European Convention on Human Rights, which regulates the presumption of innocence.

This is because the judicial authorities are looking for reducing the corruption phenomenon through coercive criminal procedural means, related to the function of punishment and implicitly to the serious degree of crime danger.

Thirdly, the doctrine of criminology has expressed contrary points of view regarding the theory of repressive application of punishments. One of them was pointed out by Cesare Beccaria, who completely combated the character of severity and intimidation of punishments ${ }^{20}$. In this regard, it was stated that the punishment usefulness makes the difference in the field of criminal sciences ${ }^{21}$. Moreover, it has been pointed out that ,the savagery of penalties is not just inhuman, but also needlessly, because not the torture rigor, but the penalty certainty may exercise a preventive role"22.

Expressing the fundamental idea that features the provisions in criminal matters regarding the logic of applying punishments, it is obvious that, from this point of view, both fundamental principles that characterize the tradition in criminal cases and novelty elements, specific for the European legal systems, should be taken into account. Nevertheless, a particular involvement of the procedural provisions in criminal matters is necessary to outline its specific effects on the judiciary. The legal doctrine has highlighted regarding the offenders that the criminal sanctions are unavoidable consequences of criminal behaviour, which assure both coercion and reeducation of those who committed offenses ${ }^{23}$.

Fourthly, applying penalty in criminal cases of corruption is a general necessity, discussed in accordance with the perpetrators'

20 AMZA, Tudor. Criminologie teoretica. Bucharest: Lumina Lex, 2000, p. 93-102.

21 AMZA, Tudor. op. cit., p. 93-102; CIOCLEI, Valerian. Manual de criminologie, Eight (ed). Bucharest: C.H. Beck, 2019, p. 62-71.

22 Idem, p. 66.

23 GAMBA, Astrid; IMMORDINO, Giovanni; PICCOLO, Salvatore. Corruption, organized crime and the bright side of subvention of law. Journal of Public Economics, v. 159, p. 79-88, 2018. 
behaviour during the criminal proceedings, who have understood that this is the only one judicial way to accept the consequences of crime committed. For this reason, both the issue of usefulness of applying punishment and its severity, as detailed by Beccaria will be taken into account ${ }^{24}$ by the courts of law during the process of achieving justice in criminal cases of corruption.

Moreover, applying penalty in criminal cases of corruption is part of the judicial bodies' activity of maintaining high standard of the principle of correlation the crime committed with the appropriate penalty. The concept has been appreciated as a „serious argument in the support of its existence and an argument that the punishment is the main and immediate mean of fighting criminality"25.

Basically, the judicial system in criminal matters comprises three pillars: investigation, judgment and, if applicable, punishment, each of them being featured by specific elements provided by the criminal procedural issues. The sanctions in criminal matters, applied in cases of corruption have a significant role in achieving the goals of criminal justice. It is perceived as consequences of infringing criminal provisions. The legal doctrine has pointed out the idea of justification of applying punishment ${ }^{26}$. Thus, one of the most important theories focuses on the "justification of punishment through its diversified and discouraging character, as well as the useful character for the preserving social order" 27 .

Finally, as a form of prevention corruption and a mean of punishing perpetrators, the penalties are featured under the coercive force. In this matter, the legal doctrine has pointed out that "applying

24 OANCEA, Ioan. Probleme de criminologie. Bucharest: All International, 1998, p. 175.

25 KELLENS, Georges. Précis de pénologie et de droit des sanctions pénales. Faculté de Droit de Liège, 1991, p. 19; OANCEA, Ioan. op. cit., p. 183.

26 CIOCLEI, Valerian. op. cit., p. 65-66; MAGHERESCU, Delia. Recunoasterea vinovatiei si aplicarea pedepsei. Bucharest: Hamangiu Publishing House, 2019, p. 92-97.

27 CIOCLEI, Valerian. op. cit., p. 65. 
punishment is the exclusive competence of the courts of law, as it was stated by the principles of criminal proceedings" 28 .

Taking into account the logical structure of justice in criminal matters, applying punishment means a comprehensive element of its composition. In this regard, the legislator has stated what the consequences of infringing the provision are applied. Moreover, the legal doctrine has emphasized that the tripartite composition suits to logical concept of achieving purpose of criminal justice entirely, which states that any rule or special mean of investigating criminal cases of corruption highlights how important the activity of gathering evidence in order to prove them is.

Furthermore, the punishment in cases of corruption crimes is characterized by the fundamental principles of criminal proceedings, such as legality, individualization of criminal sanctions, personality of criminal sanctions a.s.o.

Within the framework of establishing criminal sanctions, the judicial individualization is an essential element, due to the fact that it involves the activity of both establishing and applying these sanctions by the court of $\mathrm{law}^{29}$. In these circumstances, applying criminal penalties is the judicial activity justified from at least two points of view. One of them, in order to satisfy the general principle of the function of coercing participants to social life, and another one, in order to valuate the function of the defendants' status within the judicial framework.

While the function of coercion of criminal penalties must be analyzed in accordance with the feature of deprivation of certain rights, ordered to offenders, the function of reevaluation is equally important within the process of solving criminal case. Thus, through applying criminal penalties, changing convicts' behaviour is taken into consideration, as well as their correction in accordance with the social values protected by the provisions in criminal matters. These rules are of general applicability within the process of applying penalties in criminal cases of corruption.

28 CRISU, Anastasiu. Drept procesual penal. Partea speciala. Bucharest: All Beck, 2005, p. 128-129.

29 COURT OF LAW OF CRAIOVA. Criminal Decision no. 819 of 6 June 2018. Available at: http://www.barouldolj.ro. Accessed on November 24, 2019. 
Case 2: Corruption crime under the special procedure of admitting the guilt agreement

A particular issue is also arisen in cases of corruption crimes, solved through the special procedure of admitting the guilt agreement ${ }^{30}$. It is justified by achieving both the investigation and judgment functions of criminal proceedings under special circumstances the defendants would like to finalize their conflict on corruption crimes.

Moreover, its justification appears in this context in close connection with the scope of applying penalties itself, consisting in the activity of achieving investigation procedure as well as its consequences in the judiciary. A practical situation is provided in criminal cases in which only one defendant agrees to admit the guilt and sign a guilt agreement with the prosecutor during the investigation phase. In such circumstance, what does the judicial status cover another defendant who does not agree to admit the guilt with the consequence of signing the guilt agreement? Is respected in this case the principle of presumption of innocence for the defendant who want to solve criminal case under the ordinary procedure instead of the special procedure of the admitting the guilt agreement? There are only a few questions that deserve appropriate answers, based on judicial pertinent and legal decisions stated by the judicial bodies.

On the one hand, during the special procedure of admitting the guilt agreement, the defendants have a series of advantages of particular feature, which cannot be reported to the other perpetrators of the same criminal case, due to the fact that the judicial individualization of applying penalty depends on certain factors, such as the defendants' own circumstances of committing corruption crimes ${ }^{31}$.

On the other hand, the judicial system in criminal matters is characterized by the principle of general social prevention, which cannot be realized in this circumstance, as the legal provisions state.

For this reason, it is very difficult to achieve the general prevention of society lato sensu, in criminal cases of corruption solved

30 MAGHERESCU, Delia. op. cit., 2019.

31 HIGH COURT OF CASSATION AND JUSTICE OF ROMANIA. Decision no. 443/RC/2019. Available at: https://www.scj.ro. Accessed on May 21, 2020. 
through admitting the guilt agreement, for example. In spite of this inconvenience, the prevention of committing crimes stricto sensu can produce consequences in cases investigated and judged within the special procedure of admitting the guilt agreement.

In this matter, the concept of the plurality function of investigation, which is demonstrated and resulted from its unavoidable character, when a crime of corruption is committed is still into force. Jurisprudence has stated a unanimous direction in cases of corruption crimes, in respecting provisions adopted both at the European and international level.

The jurisprudence has emphasized that the defendant has had the serious contribution in organizing the criminal group and committing the entire criminal activity ${ }^{32}$. On the one hand, his contribution is also considered under the circumstance of increasing the danger of the crime committed. On the other hand, the court of law has taken into account his sincere behaviour during the entire criminal proceedings, under the special procedure of admitting the guilt agreement with consequence on the judicial activity of reducing limits of penalty ${ }^{33}$.

The defendant has criticized the first instance sentence, which stated the guilt in accordance with the only one piece of evidence, consisting in another defendant's declaration. The main argument was centered around the idea that in criminal case there was no conclusive evidence on establishing guilt beyond any reasonable doubt. Moreover, in his opinion, the documents found during the search procedure do not provide information regarding the amount of money given as bribery to another defendant. This means fairly that, the admittance of guilt given by one defendant, uncorroborated with other means of evidence, cannot conduct automatically to establishing the guilt for another defendant in the same case.

32 HIGH COURT OF CASSATION AND JUSTICE OF ROMANIA. Decision no. 79/A/2018. Available at: https://www.scj.ro. Accessed on May 21, 2020.

33 According to the conclusions stipulated in the report of evaluation ordered in the criminal case, the defendant presents a medium-increased risk of committing crimes, having criminal record which does not involve the state of second offense. For this reason, the court of law has decided to convict defendant by imprisonment, adding a proportion of penalty till the maximum regulated by law for the crime committed. 
A practical situation is featured by the judicial status of another defendant, who did not agree to sign a guilt agreement with the prosecutor. More particularly, the judicial status involves the incidence of the principle of presumption of innocence ${ }^{34}$.

Under the above stated circumstances, the Anti-Corruption National Department of Romania has stated that this judicial stage of criminal proceedings means the finalization of criminal investigation, situation which cannot infringe the principle of presumption of innocence ${ }^{35}$.

The legal solution in this case is one based on the principle of the personality of criminal liability as well as the presumption of innocence.

As a consequence, if some defendants agree to admit the guilt, a guilt agreement will then be signed with each other, without infringing the presumption of innocence for the other defendants who do not sign the guilt agreement ${ }^{36}$.

\section{REFLECTION OF CRIMINAL SCIENCES OVER THE CORRUPTION PHENOMENON}

Supporting the fight against corruption crimes, a new concept within the criminal sciences theory has been arisen, which intensifies the role of impartial meaning over the antisocial phenomenon entirely. It is about the social response against criminality, as a reaction to the criminal product itself. Thinking in antithesis with the needs of democratic societies, the role of such reaction may be viewed also from the point of view of the individual's wish to stop antisocial phenomena, which can have as consequence diminishing corruption phenomenon ${ }^{37}$.

34 BODORONCEA, Georgiana. Acordul de recunoastere a vinovatiei. Analele Universitatii Bucuresti, 2014, p. 331.

35 COMMUNICATION no. 1022/VIII/3 of 31 October 2017, COMMUNICATION no. 892/VIII/3 of 15 September 2017 of the Anti-Corruption National Department. Available at: http://www.pna.ro.

36 MAGHERESCU, Delia. 2019a, op. cit., p. 43.

37 KUBBE, Ina; ENGELBERT, Annika. Corruption and the impact of democracy. Crime, Law and Social Change, v. 70, p. 175-178, 2018; KOLSTAD, Ivar; WIIG, Arne. Does democracy reduce corruption. Democratization, v. 23, n. 7, p. 1198-1215, 2016. 
In this context, the social response was synchronized with the judicial imperatives, consisting in carrying out two functions of the judicial system in criminal matters. Both the function of preventing crimes and the one of punishing those who are guilty of having committed them, come to complete the legal framework of solving criminal cases. The corruption crimes are not an exception to this rule, due to the fact that, on the one hand, the judicial bodies are focused on achieving both functions stated above - prevention and punishment - and, on the other hand, the activity of fighting corruption phenomenon supposes the involvement of civil society and its individuals within this approach.

De facto, it is considered that, in missing the individuals' involvement in fighting corruption, in a democratic society it is impossible to discuss about aiming such goal. In other words, an active participation of the whole society, including the judicial bodies, administrative authorities both central and local, NGOs as well as the civil society, citizens who are interested in stopping the corruption phenomenon, is essential.

From these considerations, both functions noticed earlier have a particular importance in this field. Moreover, identifying an answer to the society's need focused on the fight against corruption is impossible to be fulfilled.

Considered as serious crimes by doctrine ${ }^{38}$, the corruption crimes are featured by an deliberating element, which consists in requiring or receiving by the perpetrator the amount of money or the other undeserved gains, infringing in such manner the legal order, protected through provisions in criminal matters. Thus, the criminal sciences come to clear up the entire constitutive elements of this kind of crimes in order for the practitioners to apply the provisions of criminal procedure law, when they are faced with conflicts of corruption crime.

From the point of view of criminology, releasing factors of the corruption crimes are diversified, coming from theories and versions, provided by either analysts or practitioners in the field. Generally speaking,

38 AMARA, Ines; KHLIF, Hichem. Financial crime, corruption and tax evasion: a cross-country investigation. Journal of Money Laundering Control. v. 21, n. 4, p. 545-554, 2018. 
the dramatic division of the states' societies deepens the negative effects of the process of developing corruption phenomenon.

The unprecedented development of the serious forms of organized crimes, including the underground economy, develops the corruption phenomenon as well. Moreover, the money laundering and tax evasion phenomena are dangers, which guard the political and administrative corrupt environment ${ }^{39}$. All these aspects produce negative consequences regarding the state citizens' trust in the competent authorities as well as in the making-decision actors both at the local and national level. On this way, the investment in the economy, as specific parameters of state, is discouraged, which will conclude inevitable in undermining state of law and good governance size, as well as in threatening citizens' fundamental rights, being at present of high interest.

Doctrine has pointed out the concept of endemic corruption, as a perturbing factor of public institutions ${ }^{40}$, which particularly generates inequalities ${ }^{41}$. In fact, this kind of corruption supports serious crimes in financial field, trafficking of drugs, arms, persons, or other forms of organized crime. The same is true in cases of corruption which appear most frequently in opposition with the general indicatives of organization and administration of the public area ${ }^{42}$. Equally, the judicial system can be featured by diversified forms of corruption ${ }^{43}$, which are discovered in some cases and sanctioned in due time. The danger of generalization of this field of activity increases the frequent cases in practice, most of them requiring the rapidity of solving criminal cases.

39 KHLIF, Hichem; AMARA, Ines. Political connections, corruption and tax evasion: a cross-country investigation. Journal of Financial Crimes. v. 26, n. 2, p. 401-411, 2019.

40 EPSTEIN, Gil S.; GANG, Ira N. Inequality, Good Governance and endemic corruption, International Tax and Public Finance, v. 26, p. 999-1017, 2019.

41 LOLI, Miranda. Self-legitimation patterns in the inequality-corruption nexus. Crime, Law and Social Change, v. 70, p. 241-256, 2018.

42 WILLIAMS, Aled; DUPUY, Kendra. Deciding over nature: Corruption and environmental impact assessments. Environmental Impact Assessment Review. v. 65, p. 118-124, 2017; KEEN, Michael; SLEMROD, Joel. Optimal tax administration. Journal of Public Economics. v. 152, p. 133-142, 2017.

43 HIGH COURT OF CASSATION AND JUSTICE. Criminal Decision no. 101/A/2019. Available at: https://www.scj.ro. Accessed on May 22, 2020. 
The jurisprudence in criminal cases has stated several examples in this matter ${ }^{44}$, providing convictions in the judicial system in cases of corruption crimes. From the point of view of the protection of general interests of society, it could be appreciated that it is the most serious form of corruption, which occurs in the contemporary society. At the moment, the intensified fight at the European and international level, which was established through mechanisms of international judicial cooperation in criminal matters, has made possible the decrease of corruption cases among the civil servants at the domestic level.

\section{LEGAL INSTRUMENTS ON FIGHTING CORRUPTION CRIMES}

The legal instruments of fighting corruption crimes are juridically regulated, both by the domestic provisions adopted by states, and European and international ones.

\section{International regulations}

At the international level, the fight against corruption is still at highest score. In this regard, the United Nations Organization has permanently made efforts to diminishing phenomenon, spread all over the world. A particular attention has been given to developing countries, in which case the UN Organization adopted certain legal instruments of combating corruption crimes ${ }^{45}$.

Monitoring corruption crimes $^{46}$ at the international level is an instrument of achieving best practices in combating phenomenon. As a key factor in progress, it comprises a number of 180 countries, as well as provides information on how each of them measures up in the field. In order to perceive the level of corruption crimes in the public area, a classification has been published, as it will be provided subsequently.

44 Ibidem.

45 UNITED NATIONS CONVENTION AGAINST CORRUPTION, adopted in New York on 31 October 2003, available online at: https://www.unodc.org (accessed on 28 April 2020).

46 TRANSPARENCY INTERNATIONAL. Corruption Perceptions Index 2019. Berlin, 2020, p. 2-3. Available at: www.transparency.org/cpi. Accessed on April 28, 2020. 
The ten cleanest countries are scored between zero and one hundred points, being interpreted from highly corrupt to very clean, as it is represented in the Table 1 below.

TABLE 1. Descriptive of the ten cleanest countries in the world

\begin{tabular}{c|c|c}
\hline Country & Score & Rank \\
\hline Denmark & 87 & 1 \\
\hline New Zealand & 87 & 3 \\
\hline Finland & 86 & 4 \\
\hline Singapore & 85 & 4 \\
\hline Sweden & 85 & 4 \\
\hline Switzerland & 85 & 8 \\
\hline Norway & 84 & 9 \\
\hline Netherlands & 82 & 9 \\
\hline Germany & 80 & \\
\hline Luxembourg & 80 & 8 \\
\hline
\end{tabular}

Source: www.transparency.org

It is obvious that in the above stated countries their position on the world classification is proportional to the living standard of citizens as well as to the other criteria established by the International organization. The same organization also provides information on how some countries fight against corruption or no direction taken in this field.

Thus, there are countries where no improvement action has been taken in this direction. In this regard, the highest corrupt indicator was provided for countries, as stated in Table 2 below. 
TABLE 2. Representation of the highest corrupt ten countries in the world

\begin{tabular}{c|c|c}
\hline Country & Score & Rank \\
\hline Libya & 18 & 168 \\
\hline Korea, North & 17 & 172 \\
\hline Afghanistan & 16 & 173 \\
\hline Equatorial Guinea & 16 & 173 \\
\hline Sudan & 16 & 173 \\
\hline Venezuela & 16 & 178 \\
\hline Yemen & 15 & 179 \\
\hline Syria & 13 & 180 \\
\hline South Sudan & 9 & \\
\hline Somalia & 12 & 177 \\
\hline
\end{tabular}

Source: www.transparency.org

On the one hand, the criteria of establishing the score for each country has been based on the objective evaluation of public activities of governments and public services as well. On the other hand, a particular view has been focused on the political parties and their involvement both in the public and private sector ${ }^{47}$ and how decision making process influences over the economic power.

In this regard, the international experts on combating and preventing corruption have pointed out that "To end corruption and restore trust in politics, it is imperative to prevent opportunities for

47 ALBRECHT, James F. Public and Police Corruption in Eastern Europe. In: GOTTSCHALK, Petter; STANISLAS, Perry (org.). Public Corruption. Regional and National Perspectives on Procurement Fraud. Boca Raton: CRC Press, Taylor\&Francis Group, 2017, p. 47-71. 
political corruption and to foster the integrity of political systems"48. Certain recommendations were made, such as:

(i) Managing conflicts of interest;

(ii) Controlling financial policy;

(iii) Strengthening electoral integrity;

(iv) Eliminating preferential treatment;

(vi) Authorizing citizens;

(vii) Reinforcing local control.

Consequently, "governments must urgently address the corrupting role of big money in political party financing and the undue influence it exerts on our political systems" Delia Ferreira Rubio, Chair of the Transparency International said ${ }^{49}$.

\section{The European approach}

On the one hand, the Council of Europe has adopted a series of laws having as the main aim fighting corruption. They were ratified by each State Member, transposed in their domestic legal order, as well as implemented in their criminal justice system ${ }^{50}$. The Criminal Law Convention on Corruption is considered as "an ambitious instrument aiming at the co-ordinated criminalisation of a large number of corrupt practices. It also provides for complementary criminal law measures and for improved international co-operation in the prosecution of corruption offences. (...) Its implementation will be monitored by the Group of States against Corruption - GRECO, which started functioning on $1^{\text {st }}$ May 1999. As soon as they ratify it, States which do not already belong to GRECO will automatically become members" ${ }^{51}$.

The Convention covers a series of corruption crimes: active and passive bribery of domestic and foreign public officials; active and

48 TRANSPARENCY INTERNATIONAL, op. cit., p. 5.

49 Idem, p. 7.

50 CRIMINAL LAW CONVENTION ON CORRUPTION, adopted on 27 January 1999 in Strasbourg. Available at: https://www.coe.int. Accessed on April 28, 2020.

51 Ibidem. 
passive bribery of national and foreign parliamentarians and of members of international parliamentary assemblies; active and passive bribery in the private sector; active and passive bribery of international civil servants; active and passive bribery of domestic, foreign and international judges and officials of international courts; active and passive trading in influence; money-laundering of proceeds from corruption crimes; accounting crimes (invoices, accounting documents, etc.) connected with corruption.

On the other hand, within the European Union, the most recent legal instrument of fighting crimes that infringe the financial interests of the European Union was launched. It involves also the corruption crimes. In this matter, Directive no. 2019/1937 on reporting the infringement of the European Union law was adopted. It refers to the infringements committed by persons called as "whistleblowers" and who "play a key role in exposing and preventing such breaches and in safeguarding the welfare of society" ${ }^{22}$ as it is stipulated at Article 1 thereof.

For these reasons, the European legislator has set up mechanisms of protecting persons, necessary "not only to prevent and detect procurement-related fraud and corruption in the context of the implementation of the Union budget, but also to tackle insufficient enforcement of rules on public procurement by national contracting authorities and contracting entities in relation to the execution of works, the supply of products or the provision of services" ${ }^{53}$. The practical areas the EU Directive is involved in are very diversified, from public procurement to financial services, from internal market operations to transport safety, from protection of the environment to nuclear safety, radiation protection, safe management of spent fuel and radioactive waste ${ }^{54}$, from public health to respecting privacy and

52 DIRECTIVE (EU) 2019/1937 of the European Parliament and of the Council of 23 October 2019 on the protection of persons who report breaches of Union law, published in the Official Journal no. L 305/17 of 26 November 2019. Available at: https://eur-lex.europa.eu. Accessed on April 24, 2020.

53 Ibidem.

54 MAGHERESCU, Delia. Particularities of the forensic science investigation of transnational serious crimes. Ius Et Scientia, v. 5, n. 2, p. 55-75, 2019. 
personal data protection ${ }^{55}$, from information systems to prevention of money laundering, a.s.o.

In fact, the Directive offers protection to employees or to those who might be suffered because of the repressive measures against themselves, either direct or indirect produced, such as the suspension, reduction to a lower professional position, obstruction of promotion, diminution of salary, coercion, intimidation, discrimination or any other forms of unfair treatment at the workplace.

Consequently, the Directive imposes obligations regarding both the public authorities and private entities, encouraging persons who know information on illegal activities including corruption acts, and is addressed to the EU Member States in order to harmonize the legislation in the field of combating and preventing any form of corruption crimes ${ }^{56}$.

\section{Domestic regulations}

The domestic regulations are basically provisions in criminal matters, as well as special provisions if states have adopted such regulations in the field ${ }^{57}$. There are states that regulate special provisions of criminal procedure law in the field of investigation and judgment of serious offences, including corruption crimes. There are also aggravated criminal procedures, derogatory from the rules of ordinary procedure ${ }^{58}$. These special criminal

55 SHEN, Ce; WILLIAMSON, John B. Corruption, democracy, economic freedom, and state strength: A cross-national analysis. International Journal of Comparative Sociology, v. 46, n. 4, p. 327-345, 2005.

56 MADLOVICS, Balint; MAGYAR, Balint. From petty corruption to criminal state: A critique of the corruption perceptions index as applied to the post-communist region. Intersections. East European Journal of Society and Politics, v. 5, n. 2, p. 103-129, 2019.

57 The provisions in criminal matters regulate that the dispositions are stated in purpose to assure exercising efficiently of the judicial bodies' duties under the guarantee of the participants' rights in such a manner to respect the Constitution, the European Union legislation and the treaties on the human fundamental rights, the states are part of.

58 It is the case of Croatia and Slovakia, for example. STEPHENSON, Matthew. Specialised anti-corruption courts: Slovakia. Anti-Corruption Resource Centre, U4 Brief, n. 2, 2016; KURIAN, Matej. Recent Slovak Anti-corruption Measures, Bratislava: Transparency International Slovakia, 2012, p. 19-20. Available at: http://www.transparency.sk. Accessed on April 30, 2020. 
procedures assure the judicial bodies in the fight against the corruption crimes and are based on the principles of criminal procedure law, as well as those of solving criminal cases in a reasonable time.

De iure, the principle that features the special procedure of solving corruption crimes is that of rapidity. It influences positively the result the judicial bodies are awaiting for in such criminal cases.

\section{Conclusions}

The phenomenon of corruption cannot be dissociated from the other elements that characterize the fight against criminality, as a general rule, although it has a series of special techniques in criminal matters, which produce consequences in this field. The fundamental principles of the forensic science, along with the new techniques and scientific methods provided by this science, have contributions in the activity of criminal investigation of the corruption crimes, from several points of view.

First of all, the judicial authorities have made significant efforts in fighting corruption by applying the appropriate legal framework.

Secondly, the legislator has been aware of the danger that the entire society faces in cases in which the phenomenon of corruption will be increased in missing efficient control from the law enforcement agencies. In this matter, a more efficient legislative framework was adopted to combat the corruption phenomenon at all levels. Another legal framework, configured at the international level and at the European Union level as well, also completed this scenario.

Last but not least, doctrine has significantly contributed to controlling corruption phenomenon through theorists' involvement in programs and mechanisms conducted within the public institutions, universities and research institutes, which particularly have had a common feature - reducing as much as possible the corruption crimes. In these circumstances, rules of good practices were implemented, the law enforcement agencies should take into account of, during the process of stopping corruption phenomenon. The rules of "first aid" in combating corruption phenomenon have created the opportunity to respond to an older imperative need of the society of fighting corruption, both at the central public institutions level and the local ones too. 
Taking into consideration these arguments, it must be highlighted that the corruption crimes are still a macro-social issue, whose evolution depends equally on the competences and duties stated by the judicial bodies in criminal matters and on the citizens'behaviour and solutions adopted by themselves, as well as on their wish to contribute to restarting society.

The pandemic of SARS COV-2 crisis, that the entire world passes, is a good occasion to rethink the trajectory that the individuals will choose during the next period of time. It is considered so, because the social needs come to increase hardy the economic crisis. Concomitantly, the individuals' needs will be rethought in such a manner to lead to a better awareness that the corrupt world is fallen down and it is the moment to look at the future, living in an unvitiated and moral world, strengthened on the principles of rule of law, democracy ${ }^{59}$ and respecting fundamental rights and liberties.

\section{BiBLIOGRAPHY}

ALBRECHT, James F. Public and Police Corruption in Eastern Europe. In: GOTTSCHALK, Petter; STANISLAS, Perry (org.). Public Corruption. Regional and National Perspectives on Procurement Fraud. Boca Raton: CRC Press, Taylor\&Francis Group, 2017.

AMARA, Ines; KHLIF, Hichem. Financial crime, corruption and tax evasion: a cross-country investigation. Journal of Money Laundering Control, v. 21, n. 4, 2018, https://doi.org/10.1108/JMLC-10-2017-0059

AMZA, Tudor. Criminologie teoretica. Bucharest: Lumina Lex, 2000.

BODORONCEA, Georgiana. Acordul de recunoastere a vinovatiei. Analele Universitatii Bucuresti, Supliment, 2014.

CIOCLEI, Valerian. Manual de criminologie, Eight (ed). Bucharest: C.H. Beck, 2019. COMMUNICATION no. 238/VIII/ of 15 April 2020, COMMUNICATION no. 236/ VIII/3 of 15 April 2020, COMMUNICATION no. 234/VIII/ of 15 April 2020,

59 FERRIN, Monica. An empirical assessment of satisfaction with democracy. In: FERRIN, Monica; KRIESI, Hanspeter (org.). How Europeans view and evaluate democracy. Oxford: Oxford University Press, 2016, p. 283-306. 
COMMUNICATION no. 1022/VIII/3 of 31 October 2017, COMMUNICATION no. 892/VIII/3 of 15 September 2017 of the Anti-Corruption National Department. Available at: http://www.pna.ro. Accessed on May 26, 2020.

COURT OF LAW OF CRAIOVA. Decision no. 819 of 6 June 2018. Available at: http://www.barouldolj.ro. Accessed on November 24, 2019.

COURT OF LAW OF ORADEA. Criminal Decision no. 446 of 2015. Available at: https://legeaz.net/spete-penal-curtea-de-apel-oradea-2015/luarea-de-mita-art289-ncp-19-06-2015-jar. Accessed on September 2, 2020.

CRIMINAL DECISION no. 294/A of 24 March 2020 of the Court of Appeal of Bucharest. Available at: http://www.pna.ro. Accessed on April 26, 2020.

CRIMINAL DECISION no. 66 of 3 March 2020 of the High Court of Cassation and Justice. Available at: http://www.pna.ro. Accessed on April 26, 2020.

CRIMINAL DECISION no. 201 of 14 February 2020 of the Court of Appeal of Bacau. Available at: http://www.pna.ro. Accessed on April 26, 2020.

CRIMINAL LAW CONVENTION ON CORRUPTION, adopted on 27 January 1999 in Strasbourg. Available at: https://www.coe.int. Accessed on April 28, 2020.

CRISU, Anastasiu. Drept procesual penal. Partea speciala. Bucharest: All Beck, 2005.

DIRECTIVE (EU) 2019/1937 of the European Parliament and of the Council of 23 October 2019 on the protection of persons who report breaches of Union law, published in the Official Journal of the European Union no. L 305/17 of 26 November 2019. Available at: https://eur-lex.europa.eu. Accessed on April 24, 2020.

EPSTEIN, Gil S.; GANG, Ira N. Inequality, Good Governance and endemic corruption. International Tax and Public Finance, v. 26, 2019. https://doi.org/10.1007/ s10797-019-09542-Z

FERRIN, Monica. An empirical assessment of satisfaction with democracy. In: FERRIN, Monica; KRIESI, Hanspeter (org.). How Europeans view and evaluate democracy. Oxford: Oxford University Press, 2016.

GAMBA, Astrid; IMMORDINO, Giovanni; PICCOLO, Salvatore. Corruption, organized crime and the bright side of subvention of law. Journal of Public Economics, v. 159, 2018. https://doi.org/10.1016/j.jpubeco.2018.02.003

HIGH COURT OF CASSATION AND JUSTICE OF ROMANIA. Decision no. 443/ RC/2019, Decision no. 385/A/2019, Decision no. 381/A/2019, Decision no. 121/A/2019, Decision no. 101/A/2019, Decision no. 79/A/2018. Available at: https://www.scj.ro. Accessed on May 21, 2020. 
HUDOC. European Court of Human Rights. Available at: https://hudoc.echr.coe. int. Accessed on April 28, 2020

KEEN, Michael; SLEMROD, Joel. Optimal tax administration. Journal of Public Economics, v. 152, 2017. https://doi.org/10.1016/j.jpubeco.2017.04.006

KELLENS, Georges. Précis de pénologie et de droit des sanctions pénales. Faculté de Droit de Liège, 1991.

KHLIF, Hichem; AMARA, Ines. Political connections, corruption and tax evasion: a cross-country investigation. Journal of Money Laundering Control, v. 26, n. 2, 2019. https://doi.org/10.1108/JFC-01-2018-0004

KOLSTAD, Ivar; WIIG, Arne. Does democracy reduce corruption, Democratization, v. 23, n. 7, 2016. https://doi.org/10.1080/13510347.2015.1071797

KUBBE, Ina; ENGELBERT, Annika. Corruption and the impact of democracy. Crime, Law and Social Change, v. 70, 2018. https://doi.org/10.1007/s10611-017-9732-0

KURIAN, Matej. Recent Slovak Anti-corruption Measures, Bratislava: Transparency International Slovakia, 2012. Available at: http://www.transparency.sk. Accessed on April 30, 2020.

LOLI, Miranda. Self-legitimation patterns in the inequality-corruption nexus, Crime, Law and Social Change, v. 70, 2018, https://doi.org/10.1007/s10611-017-9729-8

MAGHERESCU, Delia. Recunoasterea vinovatiei si aplicarea pedepsei. Bucharest: Hamangiu Publishing House, 2019a.

MAGHERESCU, Delia. Particularities of the forensic science investigation of transnational serious crimes. Ius Et Scientia, v. 5, n. 2, 2019b, http://doi.org/10.12795/ IESTSCIENTIA.2019.i02.04

MADLOVICS, Balint; MAGYAR, Balint. From petty corruption to criminal state: A critique of the corruption perceptions index as applied to the post-communist region. Intersections. East European Journal of Society and Politics, v. 5, n. 2, 2019, DOI: 10.17356/ieejsp.v5i2.504.

OANCEA, Ioan. Probleme de criminologie. Bucharest: All International, 1998.

PALCU, Pavel. Necesitatea diversificarii regulilor tactice criminalistice aplicabile in cercetarea la fata locului. Pro Lege, n. 4, 2018.

POPOVA, Maria; POST, Vincent. Prosecuting high-level corruption in Eastern Europe, Communist and Post-Communist Studies. v. 51, 2018. https://doi.org/10.1016/j.postcomstud.2018.06.004 
SHEN, Ce; WILLIAMSON, John B. Corruption, democracy, economic freedom, and state strength: A cross-national analysis. International Journal of Comparative Sociology, v. 46, n. 4, 2005. https://doi.org/10.1177/0020715205059206

STANCU, Emilian. Tratat de Criminalistica. Bucharest: Universul Juridic, 2015.

STEPHENSON, Matthew. Specialised anti-corruption courts: Slovakia, U4 Brief, Anti-Corruption Resource Centre, n. 2, 2016.

TRANSPARENCY INTERNATIONAL. Corruption Perceptions Index 2019. Berlin, 2020. Available at: www.transparency.org/cpi. Accessed on April 22, 2020.

TRIF, Valentin; PETRE, Adrian. Cercetarea locului faptei in cazul constatarii infractiunilor de coruptie. Curierul Judiciar, n. 8, 2017.

UNITED NATIONS CONVENTION AGAINST CORRUPTION, adopted on 31 October 2003. Available at: https://www.unodc.org. Accessed April 28, 2020.

WILLIAMS, Aled; DUPUY, Kendra. Deciding over nature: Corruption and environmental impact assessments. Environmental Impact Assessment Review, v. 65, 2017. https://doi.org/10.1016/j.eiar.2017.05.002

\section{Additional information and author's declarations (scientific integrity)}

Conflict of interest declaration: the author confirms that there are no conflicts of interest in conducting this research and writing this article.

Declaration of authorship: all and only researchers who comply the authorship requirements of this article are listed as authors; all coauthors are fully responsible for this work in its entirety.

Declaration of originality: the author assures that the text here published has not been previously published in any other resource and that future republication will only take place with the express indication of the reference of this original publication; she also attests that there is no third-party plagiarism or self-plagiarism. 
Dados do processo editorial

(http://www.ibraspp.com.br/revista/index.php/RBDPP/about/editorialPolicies)

- Recebido em: 01/06/2020

- Controle preliminar e verificação de plágio: 28/06/2020

- Avaliação 1: 08/07/2020

- Avaliação 2: 12/07/2020

- Avaliação 3: 21/07/2020

- Decisão editorial preliminar: 18/08/2020

- Retorno rodada de correções: 03/09/2020

- Decisão editorial final: 21/09/2020
Equipe editorial envolvida

- Editor-chefe: 1 (VGV)

- Editor-associado: 1 (RO)

- Revisores: 3

\section{COMO CITAR ESTE ARTIGO:}

MAGHERESCU, Delia. Criminal Investigation of the Corruption Crimes:

Evidence and Procedure in an Interdisciplinary Approach. Revista Brasileira de Direito Processual Penal, Porto Alegre, vol. 6, n. 3, p. 1239-1270, set./dez. 2020. https://doi.org/10.22197/rbdpp.v6i3.394

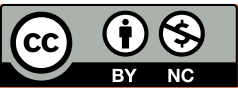

Esta obra está licenciada com uma Licença Creative Commons Atribuição-NãoComercial 4.0 Internacional. 